\title{
Article \\ Soul of the Jukskei River: The Extent of Bacterial Contamination in the Jukskei River in Gauteng Province, South Africa
}

\author{
Kousar Banu Hoorzook 1,2,*, Anton Pieterse ${ }^{2}$, Lee Heine ${ }^{2}$ (D) , Tobias George Barnard ${ }^{2}$ (D) \\ and Nickey Janse van Rensburg ${ }^{1}$
}

check for

updates

Citation: Hoorzook, K.B.; Pieterse,

A.; Heine, L.; Barnard, T.G.; van

Rensburg, N.J. Soul of the Jukskei

River: The Extent of Bacterial

Contamination in the Jukskei River in Gauteng Province, South Africa. Int. J. Environ. Res. Public Health 2021, 18, 8537. https://doi.org/10.3390/ ijerph18168537

Academic Editor: Ivone Vaz-Moreira

Received: 17 June 2021

Accepted: 28 July 2021

Published: 12 August 2021

Publisher's Note: MDPI stays neutra with regard to jurisdictional claims in published maps and institutional affiliations.

Copyright: (c) 2021 by the authors. Licensee MDPI, Basel, Switzerland. This article is an open access article distributed under the terms and conditions of the Creative Commons Attribution (CC BY) license (https:// creativecommons.org/licenses/by/ $4.0 /)$.
1 Process Energy Environment Technology Station (PEETS), Faculty of Engineering and Built Environment, University of Johannesburg, P.O. Box 17011, Doornfontein, Johannesburg 2028, South Africa; nickeyjvr@uj.ac.za

2 Water and Health Research Centre, Faculty of Health Sciences, University of Johannesburg, P.O. Box 17011, Doornfontein, Johannesburg 2028, South Africa; apieterse@uj.ac.za (A.P.); lheine@uj.ac.za (L.H.);

tgbarnard@uj.ac.za (T.G.B.)

* Correspondence: kousaro@uj.ac.za; Tel.: +27-115-596-567

\begin{abstract}
River water quality is an important health issue as the water is utilised for drinking, domestic and agricultural use in developing countries. This study aimed to investigate the effect water from a major city has on the water quality of the Jukskei River that daylights in Johannesburg, South Africa. The river water samples were analysed for physio-chemical properties, microbiology, antibiotic resistance of bacterial isolates, genetic markers, and potentially toxic metals. Data analysis revealed increased electrical conductivity, total dissolved solids, and turbidity since 2010. Total Coliform and Escherichia coli detected were above the South African water quality guidelines for domestic, recreational, and irrigation purposes. Additionally, sodium, zinc, nickel, lithium, and lead exceeded the guidelines in domestic, recreational, and irrigation water. Pathogenic strains of E. coli (aEPEC, EHEC, EIEC, and EAEC) were isolated from the water. Various other potentially pathogenic organisms that have been implicated as causes of gastro-intestinal, and a wide range of other diseases, were also detected and demonstrated multiple levels of resistance to antibiotics tested. The results show that the river water is a potential health threat to downstream users. These results will feed into the environmental management action plan for Water for the Future (NGO group).
\end{abstract}

Keywords: chemistry; Jukskei river; microbiology; molecular biology; water quality

\section{Introduction}

Safe drinking water remains inaccessible to several million people around the globe. The ever-increasing human population places severe pressure on the quality and quantity of sources of fresh drinking water and limits access to it [1]. The World Health Organization (WHO) estimates about 1100 million people, globally, drink unsafe water, and the more significant part of diarrhoeal disease $(88 \%)$ is attributed to unsafe water, and inadequate sanitation and hygiene [2].

In South Africa, the Jukskei River is one of the main rivers that confluence into the western Crocodile River basin. It is one of the three largest rivers draining the northern suburbs of the Witwatersrand and arises from an underground spring in the Bezuidenhout Valley, east of Johannesburg (Gauteng Province). It passes through a range of urban settlements such as Alexandra Township, Buccleuch, and Midrand before its confluence with the Crocodile River and flows into the Hartbeespoort dam [3]. Due to both formal and informal settlements in relation to the river, it has been subject to many water quality-related issues in the past, in particular bacterial contamination and other types of pollution such as industrial and mining effluent [4-6]. Since 1986, the Department of Water and Sanitation (DWS) has been monitoring the water quality. Previously, this river was characterised as 
having low $\mathrm{pH}(3-4)$ and high concentrations of sulfate, chloride, fluoride, sodium, and nitrate [7]. The impact of the mining activities in the surrounding areas is possibly associated with high sulfate concentrations and low $\mathrm{pH}$ [7]. The presence of high-density informal settlements near Alexandra Township has been shown to increase nutrient concentrations, sodium, chloride, and potassium [3,5].

Since DWS only monitors fundamental microbiological analysis (Total Coliform and Escherichia coli), we hypothesised that bacteria isolated from the Jukskei River would be resistant to one or more antimicrobials and be multidrug-resistant based on the occurrence of increased antimicrobial resistance of potentially pathogenic bacteria isolated from various sources in South Africa [8-10]. Recent publications regarding antimicrobial resistance of potential pathogens isolated from environmental water sources in South Africa [8-10] focused on the antimicrobial resistance of targeted bacterial species like Staphylococcus aureus, Campylobacter jejuni, and vancomycin-resistant enterococci. In addition, the present study investigated the antimicrobial resistance of a wider variety of potential bacterial pathogens not previously studied.

The aim of the current study was to investigate the effect water from the city of Johannesburg (Gauteng, South Africa) has on the Jukskei River water quality after it daylights from the city centre. The specific objectives were to identify (a) what the chemical pollution levels were, (b) identify potentially pathogenic bacteria and determine their antibiotic resistance profile, and (c) if the river water could be used directly for agricultural and recreational purposes at Victoria yards (Lorenzville, Gauteng Province, Johannesburg, South Africa) where the river daylights.

\section{Materials and Methods}

\subsection{Study Area and Sampling Site}

The Jukskei River is one of the ten river catchments in Metropolitan Johannesburg and forms part of the catchment of the Limpopo River, which flows into the Indian Ocean. It flows north through the Bezuidenhout Valley, whereby the river is covered by stormwater culverts [5]. It then flows through several residential areas and informal settlements with no or limited access to municipal services. The Jukskei passes Alexandra, an informal township - a severely overpopulated area, which creates pressure on infrastructure and blocked sewers, causing overflow into the river [3]. The Jukskei flows in a northerly direction where it joins the Crocodile River, which then flows into the Hartbeespoort Dam. Three significant tributaries that join the Jukskei before it enters the Crocodile River are the Braamfontein Spruit, Klein Jukskei Spruit, and the Modderfontein Spruit [3]. The Jukskei River catchment receives effluent from industries and runoff in vast amounts from illegal, unmanaged waste dumps, and agricultural practices [11]. The Jukskei River catchment is largely urbanised and industrialised (Figure 1) [12].

Two surface water samples (upstream and downstream) were collected each month from June to August 2018 (winter and autumn season) at the section Jukskei River which runs through Victoria Yards (Lorenzville, Central Johannesburg, South Africa). These sites were selected because it was the only sites accessible to sample the daylight section of the upper Jukskei River catchment. In this section, Victoria yards want to recycle the river water for agricultural and recreational purposes. Figure 1 provides drone pictures of the sampling sites and the geographical location of the catchment area. 


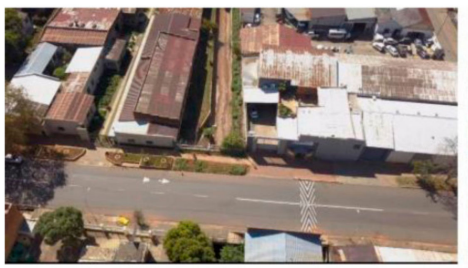

Daylights from Johannesburg city center

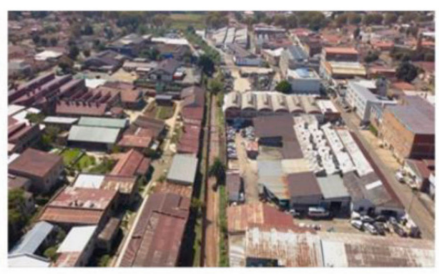

Upper Catchment of Jukskei River
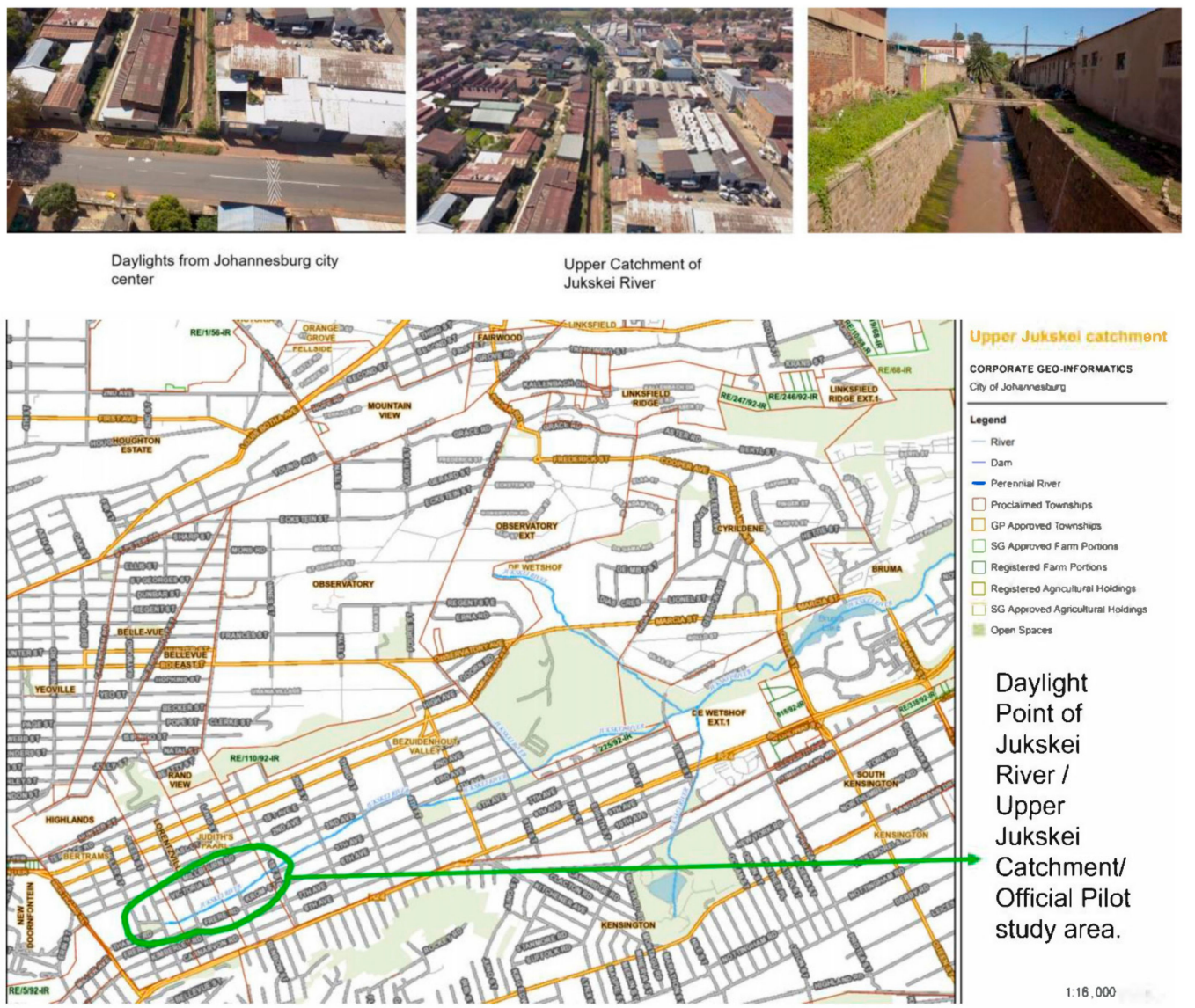

Figure 1. Drone visual and Geographical location of the upper Jukskei catchment study area (Courtesy of Joel Cruz and Water for the future).

\subsection{Sampling Collection}

Six water samples were collected in sterile $250 \mathrm{~mL}$ sampling bottles with sodium thiosulphate and kept at $4{ }^{\circ} \mathrm{C}$ en route to the laboratory. The water samples were sent to SPECTRAU within the University of Johannesburg (UJ) to analyse the heavy metals, also referred to as potentially toxic elements using inductively coupled plasma mass spectrometry (ICP-MS). Water samples were sent to UJ Water and the Health Research Centre (WHRC) for microbiology analysis.

The following physio-chemical parameters were analysed in this study, water temperature, $\mathrm{pH}$, electrical conductivity, total dissolved solids, and turbidity. The physio-chemical analysis for temperature $\left({ }^{\circ} \mathrm{C}\right)(\mathrm{HI} 98129 \mathrm{pH} /$ Conductivity/temperature, Hannah SA, Luxembourg), electrical conductivity (EC) ( $\mu \mathrm{s} / \mathrm{m}$ ) (Hannah SA, Luxembourg), $\mathrm{pH}$ (Hannah SA, Luxembourg), and total chlorine (mg/L) (Cyberscan TB1000, Eutech, Thermo Fisher Scientific, Waltham, MA, USA) was performed on-site. Before taking measurements, the instruments were calibrated according to the manufacturer's instructions. Turbidity (NTU) (YSI 900 Single Parameter Colorimeter, YSI, Yellow Springs, OH, USA) was tested in the laboratory. Total dissolved solids (TDS) were calculated using the calculation: $\operatorname{TDS}(\mathrm{mg} / \mathrm{L})=[\mathrm{EC}(\mu \mathrm{S} / \mathrm{m}) \times 0.001(\mathrm{dS} / \mathrm{m})][\mathrm{EC}(\mathrm{dS} / \mathrm{m}) \times 640(\mathrm{EC}<5 \mathrm{dS} / \mathrm{m})][13]$.

\subsection{Microbial Analysis of Water}

\subsubsection{Isolation of Total Coliforms and E. coli}

Samples were analysed within three hours of collection for bacterial quality using the Colilert ${ }^{\circledR}$ Quanti-Tray $/ 2000^{\circledR}$ (IDEXX, Westbrook, ME, USA). Enumeration of E. coli from the water was carried out using $100 \mathrm{~mL}$ of water according to the manufacturer's instructions. The Colilert ${ }^{\circledR}$ Quanti-Trays ${ }^{\circledR} / 2000$ were incubated for $18 \mathrm{~h}$ at $35^{\circ} \mathrm{C}$. After 
incubation, the Quanti-Trays ${ }^{\circledR} / 2000$ were examined under a long wave $(366 \mathrm{~nm})$ ultraviolet light, and wells that turned both yellow and fluoresced were counted as E. coli positive (IDDEX, Westbrook, ME, USA) [14].

\subsubsection{Isolation and Identification of Associated Bacteria}

Water Samples were further cultured onto deoxycholate citrate agar (DCA), thiosulphate bile-salts sucrose agar (TCBS), and sorbitol MacConkey agar (SMAC) (Oxoid, Hampshire, UK) at $37^{\circ} \mathrm{C}$ aerobically for $24-48 \mathrm{~h}$.

The resulting isolates were cultured onto Müller Hinton Agar (Oxoid, Hampshire, UK) at $37{ }^{\circ} \mathrm{C}$ for $18-24 \mathrm{~h}$. Samples were also cultured in duplicate on Campylobacter blood-free selective agar and incubated at $42{ }^{\circ} \mathrm{C}$ (one aerobically and in $5-10 \%$ carbon dioxide). Selected colonies from pure cultures were suspended in $0.45 \%$ saline solution (bioMérieux Inc., Marcy l'Etoile, France), and the density was determined using the VITEK ${ }^{\circledR}$ 2 DensiCHEK ${ }^{\mathrm{TM}}$. Bacterial suspensions were adjusted to a $0.5-0.63 \mathrm{McF}$ carland standard for Gram-positive cocci and Gram-negative bacilli, and a 1.8-2.2 McFarland standard for Gram-positive bacilli isolates.

Gram-positive bacilli and yeast isolated were identified using BCL and YST identification cards, respectively, and the VITEK ${ }^{\circledR} 2$ Compact automated system (bioMérieux Inc., Marcy l'Etoile, France). Antimicrobial susceptibility testing (AST) cards are unavailable for yeasts and Gram-positive bacilli. Therefore, these isolates were not subjected to AST in the present study. Gram-negative bacilli and Gram-positive cocci were identified using GN and GP identification cards and subjected to AST using N256 and P645 AST cards, respectively, and the VITEK ${ }^{\circledR} 2$ Compact system (bioMérieux Inc., Marcy l'Etoile, France). Details of categories and concentration ranges of antimicrobials tested using the AST-P645 and AST-N256 cards are shown in Tables S1 and S2 in the supplementary material.

The analysis was completed within $24 \mathrm{~h}$, and isolates were identified using the VITEK ${ }^{\circledR}$ 2 Compact System software. Minimum inhibitory concentrations (MICs) for each antimicrobial tested against each isolate were interpreted as either susceptible (S), intermediately resistant $(\mathrm{I})$, or resistant $(\mathrm{R})$. Isolates were then defined as exhibiting multidrug resistance (MDR), extensive drug resistance (XDR), or pan drug resistance (PDR) according to the guidelines set out by Magiorakos et al. [15].

\subsection{Molecular Detection of Identified Bacteria}

\subsubsection{DNA Extraction and Multiplex Polymerase Chain Reaction (m-PCR)}

The E. coli results from the Colilert ${ }^{\circledR}$ Quanti-Tray ${ }^{\circledR} / 2000$ were further classified as diarrhoeagenic or commensal E. coli. DNA was extracted as reported by Omar et al. [14], and 11 gene m-PCR was performed as written by Omar et al. [16]. Briefly, a total of $2 \mathrm{~mL}$ of the media was removed from up to ten positive E. coli wells of the Colilert Quanti-Trays ${ }^{\circledR} / 2000$ with sterile $1 \mathrm{~mL}$ Neomedic disposable syringes with a mounted needle (Kendon Medical Supplies, Sandton, South Africa) and aliquoted into $2 \mathrm{~mL}$ sterile Eppendorf tubes. The tubes were centrifuged for $2 \mathrm{~min}$ at $13,000 \times g$ to pellet the cells and the supernatant was discarded. DNA was extracted from the collected bacterial cells using an adapted version of the guanidium thiocyanate/silica method and homemade spin columns reported by Omar et al. [14]. DNA was eluted from the celite with $100 \mu \mathrm{L}$ Qiagen ${ }^{\circledR}$ elution buffer (Southern Cross Biotechnology ${ }^{\circledR}$, Randburg, South Africa). The extracted DNA was used as a template in all PCR reactions.

All m-PCR reactions were performed in a Biorad Mycycler ${ }^{\mathrm{TM}}$ (Dubai, United Arab Emirates) thermal cycler in a total reaction volume of $20 \mu \mathrm{L}$. A hotstart multiplex PCR kit (Qiagen ${ }^{\circledR}$, Hilden, Germany) was used for the m-PCR protocol. Each reaction consisted of 1X Qiagen ${ }^{\circledR}$ PCR multiplex mix (containing HotstartTaq ${ }^{\circledR}$ DNA polymerase, multiplex PCR buffer, and dNTP mix); $2 \mu \mathrm{L}$ of the primer mixture ( $0.1 \mathrm{lM}$ of $m d h$ and $l t$ primers [Forward (F) and reverse (R)), $0.2 \mathrm{lM}$ of ial, eagg primers, ast $A$ primers, bfp primers, and gapdh primers (F and R), $0.31 \mathrm{M}$ of eae $A$ and stx 2 primers (F and R), $0.5 \mathrm{lM}$ of stx 1 and st primers (F and R) [16]; $2 \mu \mathrm{L}$ of sample DNA, $1 \mu \mathrm{L}$ of gapdh cDNA and $5 \mu \mathrm{L}$ PCR grade water. 
The reactions were subjected to an initial activation step at $95{ }^{\circ} \mathrm{C}$ for $15 \mathrm{~min}$, followed by 35 cycles consisting of denaturing at $94{ }^{\circ} \mathrm{C}$ for $45 \mathrm{~s}$, annealing at $55^{\circ} \mathrm{C}$ for $45 \mathrm{~s}$, extension at $68{ }^{\circ} \mathrm{C}$ for $2 \mathrm{~min}$ and final elongation at $72{ }^{\circ} \mathrm{C}$ for $5 \mathrm{~min}$. DNA was visualised using a $2.5 \%$ $(w / v)$ agarose gel in TAE buffer $(40 \mathrm{mmol} / \mathrm{L}$ Tris-acetate; $2 \mathrm{mmol} / \mathrm{L}$ EDTA, pH 8.3) with $0.5 \mathrm{lg} \mathrm{mL} \mathrm{mL}^{-1}$ ethidium bromide. Electrophoresis was performed for $1-2 \mathrm{~h}$ in an electric field strength of $8 \mathrm{~V} \mathrm{~cm}^{-1}$ gel and the DNA was visualised with UV light (Syngene, Cambridge, UK). This procedure was followed for all the experiments except where stated differently. The relative sizes of the DNA fragments were estimated by comparing their electrophoretic mobility with that of the standards run with the samples on each gel, either with a $1 \mathrm{kB}$ or 100 bp marker (Fermentas, Waltham, MA, USA) [16].

The Vibrio spp. was further classified as Vibrio cholerae 01 or 0139 as reported by Ntema et al. [17]. The m-PCR targeted $V$. cholerae $\mathrm{O} 1$ and $V$. cholerae $\mathrm{O} 139 \mathrm{rfb}$ genes, ctxA (cholera toxin), and the $16 \mathrm{~S}$ rRNA gene. The Vibrio spp. PCR product Genomic DNA was sent to Inqaba Biotechnical Industries S.A. (Pretoria, South Africa) a commercial NGS service provider, for sequencing. Briefly, genomic DNA samples were PCR amplified using a universal primer pair 341F and 785R - targeting the V3 and V4 region of the $16 \mathrm{~S}$ rRNA gene. The resulting amplicons were gel purified, end-repaired and Illumina-specific adapter sequences were ligated to each amplicon. Following quantification, the samples were individually indexed, and another purification step was performed. Amplicons were then sequenced on the Illumina MiSeq platform, using a MiSeq v3 (600 cycle) kit. $20 \mathrm{Mb}$ of data $(2 \times 300 \mathrm{bp}$ long paired-end reads) were produced for each sample. The BLAST-based data analysis was performed using an Inqaba in-house developed data analysis pipeline.

\subsubsection{Potentially Toxic Elements}

A total of six water samples was analysed for potentially toxic elements using (ICPMS). The potentially toxic elements analysed were lithium, beryllium, boron, sodium, aluminium, vanadium, chromium, manganese, iron, copper, nickel, cobalt, zinc, arsenic, selenium, molybdenum, cadmium, uranium, and lead.

\subsection{Statistical Analysis}

Descriptive statistical analysis of the physio-chemical and microbiological parameters was analysed to summarise the data obtained for the three months. Variations in physical chemistry and microbiological parameters across sampling for the 3 months were analysed by one-way analysis of variance (ANOVA). The statistical analysis was performed using GraphPad Prism 9 (GraphPad Software, San Diego, CA, USA).

\section{Results and Discussion}

\subsection{Physio-Chemical Analysis}

All the analysed physio-chemical parameter levels for recreational and irrigation water were within acceptable limits according to the South African Water Quality guidelines [18]. No significant statistical variation was observed $(p<0.05)$ for the physio-chemical parameters between the two sites (upstream and downstream). The water temperature ranged from 13.07 to $19^{\circ} \mathrm{C}$ (mean $15.9^{\circ} \mathrm{C}$ ) and did not show any significant variation $(p=0.184$ ) for June-August 2018. Although the water temperature is highly variable, it is an important parameter in aquatic systems as it affects the rate of metabolic activities in organisms, it can also increase the toxicity of certain chemicals in the water [18,19]. The temperature recorded was within the range for aquatic ecosystems in the Jukskei catchment of 11.9 to $29.9^{\circ} \mathrm{C}$ [5]. The $\mathrm{pH}$ ranged from 7.11 to 7.38 (mean 7.31) and did not show any significant variation $(p=0.576)$. The $\mathrm{pH}$ stayed relatively consistent at the Jukskei River from 2009 as reported by Matowanyika et al. [5], with the same trend in $\mathrm{pH}$ also reported in the Senqu-Orange River and Mohokare River [20]. The electrical conductivity ranged from 420 to $472 \mu \mathrm{S} / \mathrm{m}$ (mean $441 \mu \mathrm{S} / \mathrm{m}$ ) with no significant variation $(p=0.148)$ shown. For most freshwaters, EC ranges from 10 to $1000 \mu \mathrm{S} / \mathrm{m}$, and elevated levels of above $1000 \mu \mathrm{S} / \mathrm{m}$ can be seen in polluted water that receives large volumes of land runoff [21]. In streams 
and rivers, conductivity is affected by various factors such as type of soils, bedrocks, presence of inorganic dissolved solids sewage, and wastewater. The EC increased from 1994 to $2008(30-80 \mu \mathrm{S} / \mathrm{m})$ as reported by Matowanyika et al. [5] to $441 \mu \mathrm{S} / \mathrm{m}$ in the current study. Total dissolved solids (TDS) ranged between 269 to $302 \mathrm{mg} / \mathrm{L}$ (mean $282 \mathrm{mg} / \mathrm{L}$ ) and did not show significant variation $(p=0.193)$. TDS increased from $10-104 \mathrm{mg} / \mathrm{L}$ in 2010 to $260-302 \mathrm{mg} / \mathrm{L}$ [5]. TDS is directly proportional to the concentration of EC and this relationship concurs with the report from Chatanga et al. [20]. Total chlorine was $0 \mathrm{~g} / \mathrm{L}$ and turbidity ranged from 35.9 to 85.7 NTU (mean 50.4 NTU) (Table 1). Turbidity did not show significant variation ( $p=0.153$ ) for June to August 2018. However, the turbidity increased from 27.1 NTU in 2010 to a mean of 50.3 NTU [5]. Turbidity normally increases in South African rivers during the rainy season. However, June-August is cold and dry. Increased microbial load and anthropogenic activities such as road and bridge construction can result in increased levels of turbidity and TDS [5,22].

Table 1. Descriptive statistics for the physio-chemical and microbiology results from June to August 2018.

\begin{tabular}{|c|c|c|c|c|c|}
\hline Test & Unit & Min & Max & Mean & $\begin{array}{l}\text { Standard } \\
\text { Deviation }\end{array}$ \\
\hline \multicolumn{6}{|c|}{ Physio-Chemical Analysis } \\
\hline $\mathrm{pH}$ & & 7.11 & 7.38 & 7.31 & 0.09 \\
\hline Turbidity & NTU & 35.9 & 85.7 & 52.4 & 5.5 \\
\hline Electrical conductivity & $\mu \mathrm{S} / \mathrm{m}$ & 420 & 472 & 441 & 15.8 \\
\hline Temperature & ${ }^{\circ} \mathrm{C}$ & 13.8 & 19 & 15.9 & 0.64 \\
\hline Total dissolved solids & $\mathrm{mg} / \mathrm{L}$ & 269 & 302.1 & 282 & 9.91 \\
\hline \multicolumn{6}{|c|}{ Microbiology Analysis } \\
\hline Total coliforms & $\mathrm{MPN} / 100 \mathrm{~mL}$ & $4.1 \times 10^{6}$ & $3.9 \times 10^{7}$ & $1.8 \times 10^{7}$ & $3.5 \times 10^{6}$ \\
\hline Escherichia coli & $\mathrm{MPN} / 100 \mathrm{~mL}$ & $8.9 \times 10^{5}$ & $4.0 \times 10^{6}$ & $2.1 \times 10^{6}$ & $1.3 \times 10^{5}$ \\
\hline
\end{tabular}

\subsection{Microbiology Analysis}

\subsubsection{Isolation of TC (Total Coliforms) and E. coli}

Six water samples were analysed with the Colilert ${ }^{\circledR}$ Quanti-Tray ${ }^{\circledR} / 2000$ method for the presence and microbial load of TC and E. coli. The TC counts ranged from $3.2 \times 10^{6}$ to $4.0 \times 10^{7}$ Most Probable Number $(\mathrm{MPN} / 100 \mathrm{~mL})\left(\right.$ mean $\left.1.8 \times 10^{7} \mathrm{MPN} / 100 \mathrm{~mL}\right)$ and did not show any significant statistical variation $(p=0.103)$ for June-August 2018. E. coli counts ranged between $8.9 \times 10^{5}-4.0 \times 10^{6} \mathrm{MPN} / 100 \mathrm{~mL}\left(\right.$ mean $\left.2.1 \times 10^{6} \mathrm{MPN} / 100 \mathrm{~mL}\right)$ (Table 1$)$ and showed significant statistical variation $(p=0.048)$. These values are above the South African Water Quality guidelines [19] for irrigation and recreational use. No significant statistical variation was observed $(p<0.05)$ for TC and E. coli between the two sites (upstream and downstream). The E. coli values detected in 2003 were in the range of $3 \times 10^{5} \mathrm{cfu} / \mathrm{mL}$ and in 2010 the values were $1 \times 10^{5} \mathrm{cfu} / \mathrm{mL}$ [5]. Microorganisms have been reported to be positively related to turbidity, total suspended solids, and TDS [20]. This can be seen with the high levels of turbidity and TDS reported in Section 3.1. An important factor that should be considered in disinfection is the turbidity of the water; the reason is that when water contains colloidal particles, they may shield the microorganisms from the action of the disinfection or react with the chlorine and in this way prevent effective disinfection [23]. E. coli is generally regarded as a specific microbial indicator of faecal pollution from humans and warm-blooded animals [24] but also have various highly pathogenic types within the group capable of causing diseases such as diarrhoea, dysentery, kidney failure, bladder infections, septicaemia, pneumonia, and meningitis $[25,26]$. 


\subsubsection{Isolation and Identification of Associated Bacteria \\ Microbiology Analysis}

The WHO released its priority list of antibiotic-resistant bacteria grouped into three tiers: critical high priority (Acinetobacter baumannii, Pseudomonas aeruginosa, Klebsiella pneumoniae, Escherichia coli, Enterobacter spp., Serratia spp., Proteus spp., Providencia spp., and Morganella spp.), high priority (Enterococcus faecium, Staphylococcus aureus, Helicobacter pylori, Campylobacter, Salmonella spp., and Neisseria gonorrhoeae) and medium priority (Streptococcus pneumoniae, Haemophilus influenzae, and Shigella spp.) [27] Within these tiers, a group of bacterial pathogens commonly referred to as the "ESKAPE" pathogens (Enterococcus faecium, Staphylococcus aureus, Klebsiella pneumoniae, Acinetobacter baumannii, Pseudomonas aeruginosa, and Enterobacter spp.) contribute significantly to the burden of disease in both developed and developing countries due to their ability to carry and easily acquire multiple antibiotic-resistant genes [28-31]. The organisms are opportunistic pathogens implicated in both nosocomial infections and community-acquired outbreaks [32]. These pathogens are of concern especially for vulnerable groups using untreated water. In Table 2, 129 isolates were identified and confirmed with the VITEK ${ }^{\circledR} 2$ Compact System, these isolates belong to 35 different bacterial species. From Table 2, it can be seen that four out of six of these "ESKAPE" pathogens were present in the water, namely Acinetobacter baumannii, Pseudomonas aeruginosa, Klebsiella pneumoniae, and Staphylococcus aureus. The table further shows potential infections various other organisms can cause such as meningitis, gastroenteritis, urinary tract infections, corneal infections, bloodstream infections, soft tissue, and skin infections, etc.

Table 2. List of bacterial species $(n=35)$ identified and confirmed with the VITEK ${ }^{\circledR} 2$ Compact System.

\begin{tabular}{|c|c|c|c|}
\hline Organism & Nr. of Isolate/s per Specie & Associated Human Disease & Reference \\
\hline Acinetobacter baumannii & 2 & $\begin{array}{l}\text { Bloodstream infection, Endocarditis, Meningitis, } \\
\text { Ophthalmitis/keratitis, Peritonitis, neumonia, Soft } \\
\text { tissue/skin infections, Urinary tract infections, } \\
\text { Wound infections }\end{array}$ & [33-35] \\
\hline Acinetobacter lwoffii & 1 & $\begin{array}{l}\text { Gastroenteritis, Meningitis, Pneumonia, Septicaemia, } \\
\text { Skin infections, Urinary tract infections }\end{array}$ & [36] \\
\hline $\begin{array}{l}\text { Aerococcus } \\
\text { viridans }\end{array}$ & 2 & $\begin{array}{l}\text { Bacteraemia, Cellulitis, Endocarditis, Soft tissue } \\
\text { infection, Urinary tract infections }\end{array}$ & [37-41] \\
\hline $\begin{array}{l}\text { Aeromonas } \\
\text { sobria }\end{array}$ & 10 & $\begin{array}{c}\text { Bacteraemia, Sepsis, Traveller's diarrhoea, Urinary } \\
\text { tract infections }\end{array}$ & {$[42,43]$} \\
\hline $\begin{array}{l}\text { Aeromonas } \\
\text { hydrophila }\end{array}$ & 22 & $\begin{array}{c}\text { Gastroenteritis, Peritonitis, Sepsis, Septicaemia, } \\
\text { Traveller's diarrhoea }\end{array}$ & {$[42,43]$} \\
\hline $\begin{array}{l}\text { Aeromonas } \\
\text { caviae }\end{array}$ & 22 & $\begin{array}{c}\text { Keratitis, Traveller's diarrhoea, Urinary tract } \\
\text { infections }\end{array}$ & {$[42,43]$} \\
\hline $\begin{array}{l}\text { Bacillus } \\
\text { pumilus }\end{array}$ & 1 & $\begin{array}{c}\text { Catheter infection, Necrotic skin infection, Sepsis, } \\
\text { Septic arthritis }\end{array}$ & [43-47] \\
\hline $\begin{array}{l}\text { Candida } \\
\text { lusitaniae }\end{array}$ & 1 & Fungemia and Prosthetic joint infection & {$[48,49]$} \\
\hline Citrobacter braakii & 4 & Bacteraemia and Urinary tract infections & {$[50,51]$} \\
\hline Citrobacter freundii & 4 & Bacteraemia, Diarrheal, Urinary tract infections & [52-54] \\
\hline $\begin{array}{l}\text { Comamonas } \\
\text { testosterone }\end{array}$ & 1 & $\begin{array}{l}\text { Appendicitis, Bacteraemia, Catheter-related infection, } \\
\text { Cholesteatoma, Endocarditis, Gastroenteritis }\end{array}$ & [55-58] \\
\hline Enterobacter asburiae & 1 & $\begin{array}{l}\text { Bloodstream infections, Osteomyelitis, Pneumonia, } \\
\text { Soft-tissue and skin infections, Urinary tract infections }\end{array}$ & [59] \\
\hline Enterococcus faecalis & 8 & Sepsis and Urinary tract infection & {$[60]$} \\
\hline $\begin{array}{l}\text { Enterococcus } \\
\text { hirae }\end{array}$ & 1 & Bacteraemia, Pyelonephritis, Urinary tract infection & [61-64] \\
\hline
\end{tabular}


Table 2. Cont

\begin{tabular}{|c|c|c|c|}
\hline Organism & Nr. of Isolate/s per Specie & Associated Human Disease & Reference \\
\hline Escherichia coli & 14 & Diarrheal, Gastroenteritis, Urinary tract infections & {$[53,54,60,65]$} \\
\hline $\begin{array}{c}\text { Gemella } \\
\text { haemolysans }\end{array}$ & 1 & Bacteraemia, Brain abscess, Endocarditis & [66-68] \\
\hline $\begin{array}{l}\text { Gemella } \\
\text { morbillorum }\end{array}$ & 1 & Brain abscess, Endocarditis, Keratitis & [69-71] \\
\hline $\begin{array}{l}\text { Klebsiella } \\
\text { pneumoniae }\end{array}$ & 1 & $\begin{array}{l}\text { Bacteraemia, Cystitis, Meningitis, Pneumonia, } \\
\text { Pyelonephritis, Pyogenic liver abscess, Sepsis, } \\
\text { Septicaemia, Soft-tissue infections, Urinary tract } \\
\text { infections, Wound infections }\end{array}$ & [72-75] \\
\hline $\begin{array}{l}\text { Kluyvera } \\
\text { ascorbate }\end{array}$ & 2 & Diarrheal, Sepsis, Urinary tract infection & {$[76,77]$} \\
\hline $\begin{array}{c}\text { Kluyvera } \\
\text { cryocrescens }\end{array}$ & 1 & $\begin{array}{c}\text { Bacteraemia, Cholecystitis, Sepsis, Soft-tissue } \\
\text { infections }\end{array}$ & [76-78] \\
\hline $\begin{array}{l}\text { Micrococcus } \\
\text { luteus }\end{array}$ & 4 & $\begin{array}{l}\text { Brain abscess, Meningitis, Myocarditis, Periprosthetic } \\
\text { joint infection, Pyogenic liver abscess }\end{array}$ & [79-81] \\
\hline $\begin{array}{l}\text { Providencia } \\
\text { alcalifaciens }\end{array}$ & 1 & Diarrheal, Gastroenteritis, Keratitis & [82-85] \\
\hline $\begin{array}{l}\text { Pseudomonas } \\
\text { aeruginosa }\end{array}$ & 2 & Respiratory tract infections, Soft-tissue infections & [86] \\
\hline Pseudomonas fluorescens & 2 & Bloodstream infection and Meningitis & [87-89] \\
\hline Pseudomonas stutzeri & 2 & $\begin{array}{l}\text { Corneal infection, Endocarditis, Prosthetic joint } \\
\text { infection, Urinary tract infection }\end{array}$ & [90-94] \\
\hline Raoultella planticola & 2 & $\begin{array}{l}\text { Bacteraemia, Bloodstream infections, Cholecystitis, } \\
\text { Necrotizing fasciitis, Pancreatitis, Pneumonia, Urinary } \\
\text { tract infection }\end{array}$ & [95-99] \\
\hline $\begin{array}{c}\text { Serratia } \\
\text { plymuthica }\end{array}$ & 2 & Osteomyelitis, Sepsis, Urinary tract infection & {$[100,101]$} \\
\hline $\begin{array}{l}\text { Shewanella } \\
\text { putrefaciens }\end{array}$ & 2 & $\begin{array}{c}\text { Bacteraemia, Ear infection, Skin, and soft-tissue } \\
\text { infections }\end{array}$ & [102] \\
\hline
\end{tabular}

Endocarditis, Food poisoning, Meningitis,

Osteomyelitis, Pneumonia, Prosthetic joint infection,

Septic arthritis, Septic shock, Septic Thrombophlebitis,

Skin and soft-tissue infections, Skin disease,

Staphylococcal scalded skin syndrome, Systemic

infections, Toxic shock syndrome, Urinary tract infections

\begin{tabular}{|c|c|c|c|}
\hline $\begin{array}{c}\text { Staphylococcus } \\
\text { auricularis }\end{array}$ & 1 & Bacteraemia, Periprosthetic joint infection, Vaginitis & [108-110] \\
\hline Staphylococcus cohnii & 4 & Bacteraemia, Meningitis, Urinary tract infections & [111-113] \\
\hline $\begin{array}{c}\text { Staphylococcus } \\
\text { haemolyticus }\end{array}$ & 2 & $\begin{array}{l}\text { Bloodstream infections, Endocarditis, Meningitis, } \\
\text { Peritonitis, Prosthetic joint infection, Urinary tract } \\
\text { infections, Vaginitis }\end{array}$ & $\begin{array}{l}{[103,106,107,} \\
110,114,115]\end{array}$ \\
\hline $\begin{array}{c}\text { Staphylococcus } \\
\text { vitulinus }\end{array}$ & 2 & $\begin{array}{c}\text { Bloodstream infections, Endocarditis, Pelvic } \\
\text { inflammatory disease, Peritonitis, Prosthetic joint } \\
\text { infection, Septic shock, Urinary tract infections, } \\
\text { Wound infections }\end{array}$ & {$[114,116]$} \\
\hline $\begin{array}{c}\text { Staphylococcus } \\
\text { warneri }\end{array}$ & 1 & $\begin{array}{l}\text { Bloodstream infections, Discitis, Endocarditis, } \\
\text { Infection of CSF shunts, Meningitis, Osteomyelitis, } \\
\text { Peritonitis, Prosthetic joint infection, Sepsis, Subdural } \\
\text { empyema, Urinary tract infections }\end{array}$ & $\begin{array}{l}{[103,106,108,} \\
114,117-121]\end{array}$ \\
\hline Vibrio cholerae & 1 & Cholera and Gastroenteritis & {$[65,105,122]$} \\
\hline
\end{tabular}


Figure 2 provides the antibiotic resistance profile for the 33 isolates (16 bacterial species) isolated and identified from the water samples. The bacteria selected are from a community of bacteria that are present in the water; the antibiotic profile does not indicate that all the genus or species in the water are resistant or susceptible to the antibiotics, only the selected colonies have the below antibiotic profile (Tables S3 and S4).

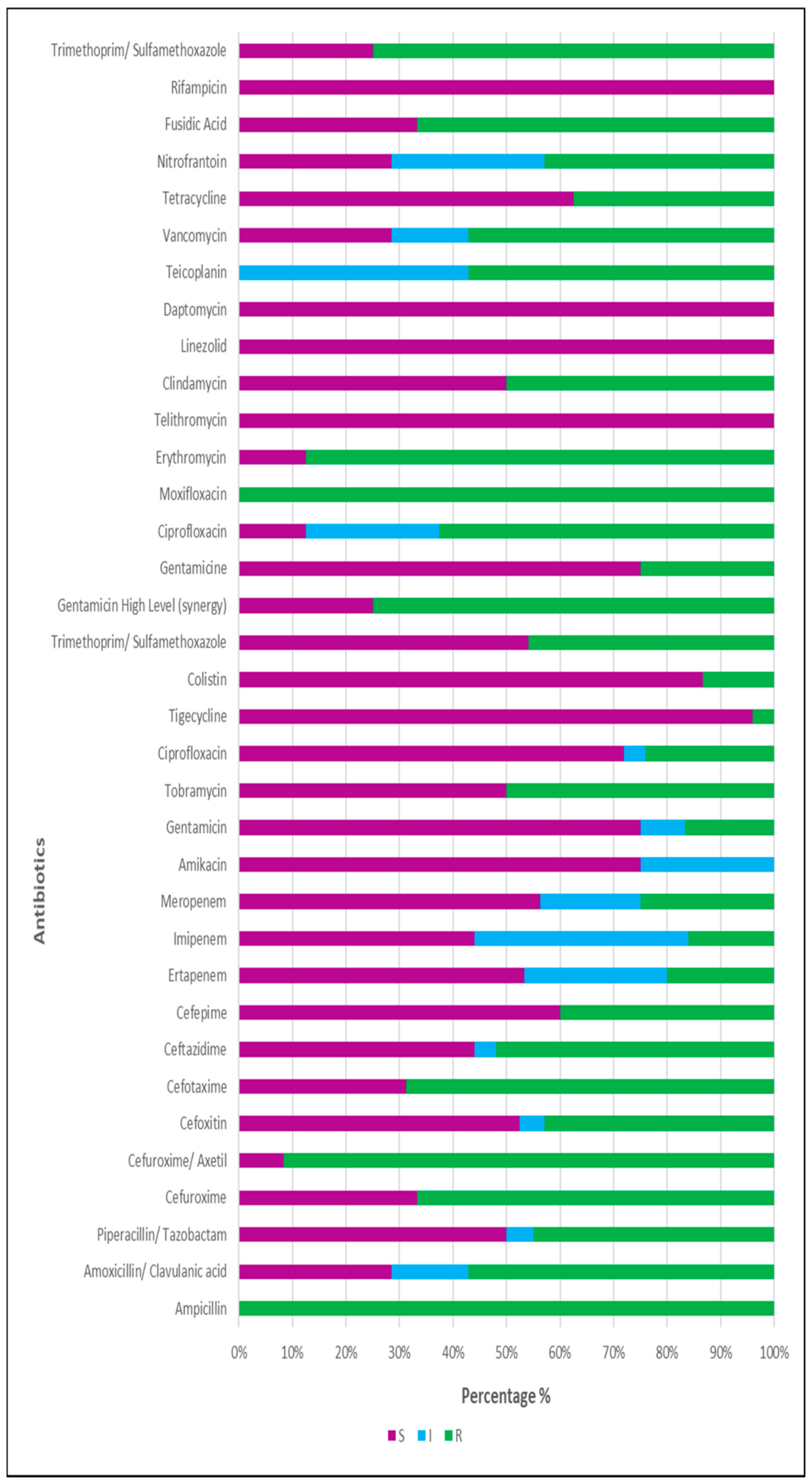

Figure 2. Percentage of bacterial isolates $(n=33)$ that are susceptible $(\mathrm{S})$, intermediately resistant $(\mathrm{I})$, or resistant $(\mathrm{R})$ to each of the listed antibiotics. 
High levels of resistance were noted in the 25 isolates subjected to antimicrobial susceptibility testing (Figure 2). Of these, $8 \%(2 / 25)$ showed resistance to none of the antimicrobials in any of the categories tested, and $20 \%(5 / 25)$ showed resistance to antimicrobials in either one or two categories. A further $72 \%(18 / 25)$ were identified as MDR isolates and were resistant to one or more antimicrobials in between three and ten categories of antibiotic drugs. No XDR or PDR isolates were identified after susceptibility testing and interpretation. Of the $18 \mathrm{MDR}$ isolates, $44 \%(8 / 18)$ were categorised as extended-spectrum $\beta$-lactamase (ESBL) producers, 33\% (6/18) of isolates showed a high level of Amp C resistance, and 22\% (4/18) were shown to be extended-spectrum carbapenemase producers or carbapenem impermeability. The resistance of two isolates to colistin is worrying as this is an antimicrobial of last resort for the treatment of MDR and XDR organisms [123,124]. The results of the present study correlate with those of Müller et al. [125], which show these highly antimicrobial-resistant organisms to be present in wastewater and environmental water sources. The majority of MDR isolates were clinically significant species-i.e., those capable of causing infection in humans. This is problematic as treatment of infection with organisms that are resistant to antibiotics is more complex and increases morbidity and mortality of infected patients [126]. The most common antibiotic-resistant, clinically relevant gram-negative species comprise ESBL- and carbapenemase-producing Enterobacteriaceae, such as Klebsiella pneumoniae and E. coli, as well as non-fermenters such as Pseudomonas aeruginosa and Acinetobacter baumannii [127], some of which form part of the "ESKAPE" pathogens and the WHOs priority list of antibiotic-resistant bacteria. The high prevalence of multidrug resistance (MDR) in the isolates subjected to AST is of concern as the bacteria isolated are responsible for community and nosocomial infection. Antimicrobial resistance increases patient morbidity and mortality and increases [126] the financial burden of disease, which is especially significant in low-income countries such as South Africa [128]. MDR was defined as non-susceptibility to one or more antimicrobials in three or more drug categories. Extensive drug resistance (XDR) was defined as non-susceptibility to one or more antimicrobials in all but two drug categories. Pan drug resistance (PDR) was defined as non-susceptibility to one or more antimicrobials in all drug categories. These definitions do not include intrinsic resistances displayed by some genera to specific antibiotics, and, therefore, only consider acquired resistance [15].

\section{Molecular Biology Analysis}

All six water samples detected the following potential pathogenic E. coli: Atypical Enteropathogenic E. coli (EPEC), Enterohaemorrhagic E. coli (EHEC), Enteroinvasive E. coli (EIEC), Enteroaggregative E. coli (EAEC), and toxin astA that can be detected in both commensal and pathogenic E. coli.

E. coli is one of the best known and earliest described human opportunistic pathogenic bacteria. It is also a specific microbial indicator of faecal pollution from humans and warmblooded animals [24]. E. coli is divided into intestinal pathogens [Diarrhoegenic E. coli $(\mathrm{DEC})]$ and extraintestinal E. coli (ExPEC), causing a variety of infections in both animals and humans, including urinary tract infections, meningitis, and septicaemia $[129,130]$. There are at least eight DEC pathotypes and four ExPEC [131,132]. Eight pathotypes are diarrhoeagenic, based on their pathogenic mechanisms; however, five DEC were selected for this study based on their importance for surface-water pathogenicity. These include the EPEC, ETEC, EHEC, EAEC, and EIEC [133,134].

The Vibrio cholerae was confirmed with m-PCR and $16 \mathrm{~S}$ rDNA sequencing as a nonpathogenic environmental isolate. Vibrio spp. has been associated with domestic sewage in the river and most Vibrio spp. enumerated are of animal origin [135].

\section{Potentially Toxic Elements}

A total of six water samples was sent to SPECTRAU within the UJ (the University of Johannesburg) to analyse the potentially toxic elements. Table 3 provides the results compared to the specified drinking, recreational, and irrigation water guidelines $[18,19]$. 
The results show that the potential toxigenic elements were within the DWS water quality guidelines for irrigation, recreation, and drinking purposes, except for $\mathrm{Li}, \mathrm{Ni}, \mathrm{Zn}, \mathrm{Pb}$, and $\mathrm{Na}$ for irrigation, recreation, and drinking purposes [18,19].

The concentration of uranium is very low, which means that the water is nonradioactive. Sodium is above the guideline for drinking water and irrigation water. The guideline for drinking water is $<200 \mu \mathrm{g} / \mathrm{L}$, and the guideline for irrigation water is $2000 \mu \mathrm{g} / \mathrm{L}$, but the average concentration for sodium is $45,545 \mu \mathrm{g} / \mathrm{L}$. Sodium is not suitable for irrigation; it causes a shortage of calcium and potassium in the soil. These are essential nutrients for plants. The deficiency of these nutrients results in the poor growth of plants. Sodium is also bad for the body if it is used excessively. It causes nausea, vomiting, and can cause heart failure [2]. According to da Silva et al. [3], high levels of sodium, above $400 \mathrm{mg} / \mathrm{L}$ with an alkaline $\mathrm{pH}$ and an increased level of phosphate, is a suitable environment for Faecal Coliforms, thus elevating the number's present in the Jukskei River. The contribution of increased levels of sodium in the water could be from soaps and sodium salts [3].

Zinc is above the guideline for drinking, recreation, and irrigation water. The guideline for drinking water is $<5 \mu \mathrm{g} / \mathrm{L}$, and the guideline for irrigation water is $100-2000 \mu \mathrm{g} / \mathrm{L}$, whereas the average concentration for zinc is $116.68 \mu \mathrm{g} / \mathrm{L}$. Toxicity in humans may occur if zinc concentration approaches $400 \mathrm{mg} / \mathrm{kg}$ and $3 \mathrm{mg} / \mathrm{L}$ in soil and water, respectively. This is characterised by symptoms of irritability, muscular stiffness and pain, loss of appetite, and nausea [22,136].

Lead is above the guideline for drinking water. The guideline for drinking water is $<10 \mu \mathrm{g} / \mathrm{L}$, whereas the concentration of lead in different samples was higher than the guideline. It has concentrations of $15.2 \mu \mathrm{g} / \mathrm{L}$ and $21.6 \mu \mathrm{g} / \mathrm{L}$. Lead is highly toxic, and its widespread use has caused extensive environmental contamination and health problems in many parts of the world [22]. The common symptom of lead poisoning is anaemia because lead interferes with the formation of haemoglobin, and prevents iron uptake. Higher levels of lead may induce permanent brain damage and kidney dysfunction. Over time, the lead substitutes $\mathrm{Ca}$ in the bones which acts to store the lead. Then in old age, the lead is reactivated by the slow dissolution of the bones [22].

Lithium is above the guideline for irrigation, recreation, and drinking. The guideline for irrigation and recreation is $<2500 \mu \mathrm{g} / \mathrm{L}$, whereas the average concentration is $2710 \mu \mathrm{g} / \mathrm{L}$. Lithium is a naturally occurring element in drinking water mainly originating from weathering of minerals in the subsurface. Lithium, in most of the world's major rivers, is derived predominantly from silicate weathering, and the fraction is derived from carbonate rocks [137].

Nickel is above the guideline for drinking, irrigation, and recreation water. The guideline is $200-2000 \mu \mathrm{g} / \mathrm{L}$, whereas the average concentration for nickel was $2279 \mu \mathrm{g} / \mathrm{L}$. Nickel is noted in exceptional cases of release from natural or industrial nickel deposits in the ground. Nickel has an extensive range of carcinogenic mechanisms, which include regulation of transcription factors, controlled expression of specific genes, and generation of free radicals [22]. Nickel is implicated in regulating the expression of specific long non-coding ribonucleic acids (RNA). It has also been demonstrated that nickel can generate free radicals, contributing to carcinogenic processes [138].

Between 1987 and 1990, the Urban Renewal Plan was implemented at the Jukskei River to reduce pollution load. A water reticulation system, water-borne sewage pipes, electrical reticulation, and ablution facilities were provided to all dwelling units in Alexandra Township within the Jukskei River catchment. This increased the number of residents, thus increasing the urban runoff and pollution load in the river [139]. Furthermore, a potential source for water pollution includes wastewater effluent and hazardous waste from manufacturing industries, and the collapse of the stormwater and wastewater infrastructure, which lies above each other, thus flowing as one when flowing out of the city centre [140]. This has several environmental impacts, such as excess storm-runoff which reaches the river bringing along the pollutants and toxicants from neighbouring land uses including industry or mining [3]. 
Table 3. Results of the ICP-MS potentially toxic elements.

\begin{tabular}{|c|c|c|c|c|c|c|c|c|c|c|c|c|c|c|c|c|c|c|c|}
\hline Sample Id & $\begin{array}{r}\mathrm{Li} 7 \\
\mu \mathrm{g} / \mathrm{L}\end{array}$ & $\begin{array}{l}\mathrm{Be} 9 \\
\mu \mathrm{g} / \mathrm{L}\end{array}$ & $\begin{array}{l}\text { B } 11 \\
\mu \mathrm{g} / \mathrm{L}\end{array}$ & $\begin{array}{l}\text { Na } 23 \\
\mu \mathrm{g} / \mathrm{L}\end{array}$ & $\begin{array}{l}\mathrm{Al} 27 \\
\mu \mathrm{g} / \mathrm{L}\end{array}$ & $\begin{array}{l}\text { V } 51 \\
\mu \mathrm{g} / \mathrm{L}\end{array}$ & $\begin{array}{l}\mathrm{Cr} 52 \\
\mu \mathrm{g} / \mathrm{L}\end{array}$ & $\begin{array}{c}\mathrm{Mn} 55 \\
\mu \mathrm{g} / \mathrm{L}\end{array}$ & $\begin{array}{l}\text { Fe } 57 \\
\mu \mathrm{g} / \mathrm{L}\end{array}$ & $\begin{array}{l}\text { Co } 59 \\
\mu \mathrm{g} / \mathrm{L}\end{array}$ & $\begin{array}{l}\mathrm{Ni} 60 \\
\mu \mathrm{g} / \mathrm{L}\end{array}$ & $\begin{array}{c}\mathrm{Cu} 63 \\
\mu \mathrm{g} / \mathrm{L}\end{array}$ & $\begin{array}{c}\mathrm{Zn} 66 \\
\mu \mathrm{g} / \mathrm{L}\end{array}$ & $\begin{array}{l}\text { As } 75 \\
\mu \mathrm{g} / \mathrm{L}\end{array}$ & $\begin{array}{l}\text { Se } 82 \\
\mu \mathrm{g} / \mathrm{L}\end{array}$ & $\begin{array}{l}\text { Mo } 98 \\
\mu \mathrm{g} / \mathrm{L}\end{array}$ & $\begin{array}{c}\mathrm{Cd} 111 \\
\mu \mathrm{g} / \mathrm{L}\end{array}$ & $\begin{array}{c}\mathrm{Pb} \mathrm{208} \\
\mu \mathrm{g} / \mathrm{L}\end{array}$ & $\begin{array}{l}\mathrm{U} 238 \\
\mu \mathrm{g} / \mathrm{L}\end{array}$ \\
\hline Upstream 1st & 4.097 & $<0.1$ & 35.5 & 48,282 & 68.9 & 1.3 & 0.6 & 52.4 & 211 & 0.6 & 3.403 & 15.2 & 23.8 & 0.8 & $<0.1$ & 0.5 & $<0.1$ & 1.1 & 0.5 \\
\hline Downstream 1st & 3.254 & $<0.1$ & 45.0 & 49,581 & 77.1 & 1.4 & 0.6 & 50.6 & 173 & 0.6 & 3.121 & 25.0 & 37.6 & 0.6 & $<0.1$ & 0.5 & $<0.1$ & 0.9 & 0.7 \\
\hline Upstream 2nd & 4.340 & $<0.1$ & 12.7 & 39,586 & 85.3 & 1.5 & 0.6 & 51.8 & 220 & 0.6 & 3.470 & 28.5 & 267 & 0.7 & $<0.1$ & 1.4 & 0.2 & 21.6 & 1.1 \\
\hline Downstream 2nd & 4.507 & $<0.1$ & 8.7 & 44,734 & 112 & 2.3 & 0.8 & 55.6 & 257 & 0.7 & 3.665 & 24.2 & 255 & 1.0 & $<0.1$ & 1.4 & 0.2 & 15.2 & 1.0 \\
\hline Upstream 3rd & 2.9 & 95.6 & $<0.1$ & 54,168 & 74.3 & 1.2 & 0.8 & 53.1 & 166 & 0.6 & 5.0 & 10.2 & 40.3 & 0.3 & $<0.1$ & 0.5 & $<0.1$ & 1.2 & 0.7 \\
\hline Downstream 3rd & 3.2 & 106.6 & $<0.1$ & 46,958 & 64.8 & 1.1 & 0.7 & 54.3 & 221 & 0.5 & 7.8 & 9.6 & 48.7 & 0.2 & 9.4 & 0.5 & $<0.1$ & 1.6 & 0.6 \\
\hline $\begin{array}{l}\text { SANS } 241 \text { Drinking water } \\
\text { Guideline (SABS, 2015) }\end{array}$ & $<2400$ & * & * & $<200$ & $<300$ & * & $<50$ & $<100$ & $<2000$ & * & $<70$ & $<2000$ & $<5$ & $<10$ & $<40$ & * & $<3$ & $<10$ & $<30$ \\
\hline $\begin{array}{l}\text { SA Irrigation water } \\
\text { guideline (DWAF, 1996) }\end{array}$ & $<2500$ & $\begin{array}{l}100- \\
5000\end{array}$ & $\begin{array}{l}500- \\
1000\end{array}$ & 2000 & $\begin{array}{c}5- \\
20,000\end{array}$ & $\begin{array}{l}100- \\
1000\end{array}$ & 100 & $\begin{array}{c}20- \\
10,000\end{array}$ & $\begin{array}{c}500- \\
20,000\end{array}$ & $50-500$ & $\begin{array}{l}200- \\
2000\end{array}$ & $\begin{array}{l}200- \\
5000\end{array}$ & $\begin{array}{l}100- \\
2000\end{array}$ & 100 & $\begin{array}{l}20- \\
50\end{array}$ & $10-50$ & $10-50$ & $\begin{array}{l}200- \\
2000\end{array}$ & $10-100$ \\
\hline
\end{tabular}




\section{Conclusions}

The aim was to investigate the effect water from the city of Johannesburg has on the water quality flowing to the lower Jukskei River catchment. The results show that even though the physical chemistry was within the South African guideline limit, the detection levels have increased from 2010 to 2018 for EC, TDS, and turbidity. Microorganisms have been reported to be positively related to turbidity and TDS. This can be seen with the TC and E. coli and the identification of associated bacteria. The TC and E. coli values were above the DWS 1996 guidelines for recreational and agricultural use and SANS 241-2:2015 guidelines for drinking water. Potential pathogenic E. coli, the "ESKAPE" pathogens, and various associated pathogenic organisms have also been detected that can cause gastrointestinal diseases, traveller's diarrhoea, skin, wound, and urinary tract infections, pneumonia, and various other diseases. These organisms detected have various levels of resistance when subjected to antimicrobial susceptibility testing. Most published articles on river water quality analysis analyse the microbial indicators to determine the extent of the pollution load and assume that pathogenic bacteria are present. In this study, results show the importance of microbial pollution in the Jukskei River in which the potential source includes domestic sewage and wastewater effluent.

For the potentially toxic elements analyses, Lithium, Nickel, Zinc, Lead, and Sodium were above the South African irrigation, recreation, and drinking water quality guidelines if the water is used for these purposes. Lead is highly carcinogenic, and Nickel causes cell damage and affects carcinogenic processes. The toxicity of potentially toxic elements could be acute, while others could be chronic after long-term exposure.

The water quality of river systems is crucial, given that rivers are systems that connect communities in space. Activities upstream have consequences on downstream users and systems. The Jukskei River water is a potential threat to people using the river as a source of recreational, agricultural, and domestic water. Furthermore, bioaccumulation of pollutants can occur in the food chain. The water is also a threat to aquatic ecosystem health and integrity.

Supplementary Materials: The following are available online at https: / www.mdpi.com/article/10 .3390 /ijerph18168537/s1, Table S1: Details of categories and concentration ranges of antimicrobials tested using the AST-P645 card, Table S2: Details of categories and concentration ranges of antimicrobials tested using the AST-N256 card, Table S3: Antimicrobial susceptibility profiles Gram-positive cocci subjected to AST, and Table S4: Antimicrobial susceptibility profiles Gram-negative bacilli subjected to AST.

Author Contributions: Conceptualization, K.B.H. and N.J.v.R.; methodology, K.B.H. and A.P.; formal analysis, A.P., L.H. and T.G.B.; investigation, K.B.H.; resources, K.B.H.; writing-original draft preparation, K.B.H.; writing-review and editing, K.B.H., A.P., L.H. and T.G.B.; supervision, T.G.B. and N.J.v.R.; project administration, K.B.H.; funding acquisition, N.J.v.R.; stakeholder engagement, N.J.v.R. All authors have read and agreed to the published version of the manuscript.

Funding: This study was supported by the University of Johannesburg Process Energy Environment Technology Station (UJ/PEETS) mandated by the Department of Science and Innovation through the Technology Innovation Agency to support technology innovation and socio-economic development in the green economy.

Institutional Review Board Statement: Not applicable.

Informed Consent Statement: Not applicable.

Data Availability Statement: Available at University of Johannesburg data repository, link https: / / figshare.com/s/330479b055d982d4065d.

Acknowledgments: Technology Innovation Agency (TIA) for the funding. Water for the Future (Romy Stander, Hannelie Coetzee, Paul Mackenzie), for allowing PEETS to participate in their project. Nando's and Victoria Yards for the access to the Jukskei River. Water and Health Research Centre members that analysed the water samples, including Zaakirah Delair and Riahaanah Paulse. 
Conflicts of Interest: The authors declare no conflict of interest. The funders had no role in the study design; in the collection, analyses, or interpretation of data; in the writing of the manuscript, or in the decision to publish the results.

\section{References}

1. Pindi, P.K.; Yadav, P.R.; Shanker, A.S. Identification of opportunistic Pathogenic bacteria in drinking water samples of different rural health centres and their clinical impacts on humans. Biomed. Res. Int. 2013, 2013, 348250. [CrossRef]

2. World Health Organization (WHO). Water, Sanitation, Hygiene, and Waste Management for SARS-CoV-2, the Virus That Causes COVID-19: Interim Guidance; World Health Organization: Geneva, Switzerland, 2020; Volume 4, pp. 1-11.

3. da Silva, J.M. A Case Study on the Historical Water Quality Trends Pertaining to the Jukskei River, in the Gauteng Province, South Africa; University of Johannesburg: Johannesburg, South Africa, 2012.

4. Taylor, J.C.; Harding, W.R.; Archibald, C.G.M.; van Rensburg, L. Diatoms as indicators of water quality in the Jukskei-Crocodile River system in 1956 and 1957, a re-analysis of diatom count data generated by BJ Cholnoky. Water SA 2005, 31, 237-246. [CrossRef]

5. Matowanyika, M. Impact of Alexandra Township on the Water Quality of the Jukskei River. Master's Thesis, University of WITS, Johannesburg, South Africa, 2010.

6. Olukenle, O.; Okonkwo, J.; Kenede, K.; Lupankwa, M. Concentration of Polybrominated Diphenyl Ethers in sediments from the Jukskei River, Gauteng South Africa. Bull. Environ. Contam. Toxicol. 2012, 88, 461-466. [CrossRef] [PubMed]

7. Huizenga, J.M.; Harmse, J.T. Geological and Anthropogenic Influences on the Water Chemistry of the Jukskei River, Gauteng, South Africa. S. Afr. J. Geol. 2005, 108, 439-447. [CrossRef]

8. Akanbi, O.E.; Njom, H.A.; Fri, J.; Otigbu, A.C.; Clarke, A.M. Antimicrobial Susceptibility of Staphylococcus aureus Isolated from Recreational Waters and Beach Sand in Eastern Cape Province of South Africa. Int. J. Environ. Res. Public Health 2017, 14, 1001. [CrossRef] [PubMed]

9. Otigbu, A.C.; Clarke, A.M.; Fri, J.; Akanbi, E.O.; Njom, H.A. Antibiotic Sensitivity Profiling and Virulence Potential of Campylobacter jejuni Isolates from Estuarine Water in the Eastern Cape Province, South Africa. Int. J. Environ. Res. Public Health 2018, 15, 925. [CrossRef] [PubMed]

10. Matlou, D.P.; Bissong, M.E.A.; Tchatchouang, C.K.; Adem, M.R.; Foka, F.E.T.; Kumar, A.; Ateba, C.N. Virulence Profiles of Vancomycin-Resistant Enterococci Isolated from Surface and Ground Water Utilized by Humans in the North-West Province, South Africa: A Public Health Perspective. Environ. Sci. Pollut. Res. Int. 2019, 26, 15105-15114. [CrossRef]

11. Department of Water Affairs and Forestry (DWAF). Water Conservation and Water Demand Management Strategy for Industry, Mining and Commercial Water Use. 2003. Available online: http:/ / www.dwaf.gov.za/WaterConservation/Programs_IMP.htm (accessed on 28 May 2021).

12. Sibali, L.L.; Okwonkwo, J.O.; McCrindle, R.I. Determination of selected organochlorine pesticide (OCP) compounds from the Jukskei River catchment area in Gauteng, South Africa. Water SA 2008, 34, 611-622, ISSN 0378-4738. [CrossRef]

13. Fipps, G. Irrigation Water Quality Standards and Salinity Management Strategies. Tex. FARMER Collect. 2003, B1667, 1-18.

14. Omar, K.B.; Potgieter, N.; Barnard, T.G. Development of a rapid screening method for the detection of pathogenic Escherichia coli using a combination of Colilert Quanti-Trays/2000 and PCR. Water Sci. Tech. Water Supply 2010, 10, 1-8. [CrossRef]

15. Magiorakos, A.P.; Srinivasan, A.; Carey, R.B.; Carmeli, Y.; Falagas, M.E.; Giske, C.G.; Harbarth, S.; Hindler, J.F.; Kahlmeter, G.; Olsson-Liljequist, B.; et al. Multidrug-Resistant, Extensively Drug-Resistant and Pan Drug-Resistant Bacteria: An International Expert Proposal for Interim Standard Definitions for Acquired Resistance. Clin. Microbiol. Infect. 2012, 18, $268-281$. [CrossRef] [PubMed]

16. Omar, K.B.; Barnard, T.G. Detection of diarrhoeagenic Escherichia coli in clinical and environmental water sources in South Africa using single-step 11-gene m-PCR. World J. Microbiol. Biotechnol. 2014, 30, 2663-2671. [CrossRef]

17. Ntema, V.M.; Potgieter, N.; Barnard, T.G. Detection of Vibrio cholerae and Vibrio parahaemolyticus by molecular and culture-based methods from source water to household container-stored water at the point-of-use in South African rural communities. Water Sci. Technol. 2010, 61, 3091-3101. [CrossRef] [PubMed]

18. Department of Water Affairs and Forestry (DWAF). South African Water Quality Guidelines, 2nd ed.; CSIR Environmental Services: Pretoria, South Africa, 1996; Volumes 1, 2 and 4.

19. SABS. South African National Standard, SANS 241-2:2015, Drinking Water Part 2: Application of SANS 241-1, 2nd ed.; SABS: Pretoria, South Africa, 2015; ISBN 978-0-626-31245-9.

20. Chatanga, P.; Ntuli, V.; Mugomeri, E.; Keketsi, T.; Chikowore, N.V.T. Situational analysis of physicochemical, biochemical, and microbiological quality of water along Mohokare River, Lesotho. Egypt. J. Aquat. Res. 2019, 45, 45-51. [CrossRef]

21. Vadde, K.K.; Wang, J.; Cao, L.; Yuan, T.; McCarth, A.J.; Sekar, R. Assessment of Water Quality and Identification of Pollution Risk Locations in Tiaoxi River (Taihu Watershed), China. Water 2018, 10, 183. [CrossRef]

22. Obasi, N.P.; Akudinobi, B.B. Potential health risk and levels of heavy metals in water resources of lead-zinc mining communities of Abakaliki, southeast Nigeria. Appl. Water Sci. 2020, 10, 184. [CrossRef]

23. Schutte, F. Handbook for the Operation of Water Treatment Works; The Water Research Commission, The Water Institute of Southern Africa: Pretoria, South Africa, 2006.

24. Cloete, T.E.; Rose, J.; Nel, L.H.; Ford, T. Microbial Waterborne Pathogens; IWA Publishing: London, UK, 2004 ; pp. 5-10. 
25. Water Research Commission (WRC). The Department of Water Affairs and Forestry (DWAF) and Department of Health. In South African Water Quality Guidelines: Volume 2-Recreational Use, 2nd ed.; Water Research Commission: Pretoria, South Africa, 1996.

26. Water Research Commission (WRC). The Department of Water Affairs and Forestry (DWAF), and Department of Health. In South African Water Quality Guidelines for Recreational Water Use; Holmes, S., Ed.; CSIR Environmental Services: Pretoria, South Africa, 1996; Volume 2.

27. WHO. Essential Medicines and Health Products: Global Priority List of Antibiotic-Resistant Bacteria to Guide Research, Discovery, and Development of New Antibiotics. Available online: http://www.who.int/medicines/publications/global-priority-listantibiotic-resistant-bacteria (accessed on 9 June 2021).

28. Bodro, M.; Sabé, N.; Tubau, F.; Lladó, L.; Baliellas, C.; Roca, J.; Cruzado, J.M.; Carratalà, J. Risk factors and outcomes of bacteremia caused by drug-resistant ESKAPE pathogens in solid-organ transplant recipients. Transplantation 2013, 96, 843-849. [CrossRef] [PubMed]

29. Mücke, M.M.; Kessel, J.; Mücke, V.T.; Schwarzkopf, K.; Hogardt, M.; Stephan, C.; Zeuzem, S.; Kempf, V.A.; Lange, C.M. The role of Enterococcus spp. and multidrug-resistant bacteria causing pyogenic liver abscesses. BMC Infect. Dis. 2017, 17, 450. [CrossRef]

30. Ramsamy, Y.; Essack, S.Y.; Sartorius, B.; Patel, M.; Mlisana, K.P. Antibiotic resistance trends of ESKAPE pathogens in KwazuluNatal, South Africa: A five-year retrospective analysis. Afr. J. Lab. Med. 2018, 7, 1-8. [CrossRef]

31. Tacconelli, E.; Carrara, E.; Savoldi, A.; Harbarth, S.; Mendelson, M.; Monnet, D.L.; Pulcini, C.; Kahlmeter, G.; Kluytmans, J.; Carmeli, Y.; et al. Discovery, research, and development of new antibiotics: The WHO priority list of antibiotic-resistant bacteria and tuberculosis. Lancet Infect. Dis. 2018, 18, 318-327. [CrossRef]

32. Dalton, K.R.; Rock, C.; Carroll, K.C.; Davis, M.F. One Health in hospitals: How understanding the dynamics of people, animals, and the hospital built-environment can be used to better inform interventions for antimicrobial-resistant gram-positive infections. Antimicrob. Resist. Infect. Control 2020, 9, 78. [CrossRef] [PubMed]

33. Almasaudi, S.B. Acinetobacter spp. as nosocomial pathogens: Epidemiology and resistance features. Saudi. J. Biol. Sci. 2018, 25, 586-596. [CrossRef]

34. Navidinia, M. The clinical importance of emerging ESKAPE pathogens in nosocomial infections. J. Paramed. Sci. $2016,7,43-57$.

35. Higgins, P.G.; Hrenovic, J.; Seifert, H.; Dekic, S. Characterization of Acinetobacter baumannii from water and sludge line of secondary wastewater treatment plant. Water Res. 2018, 140, 261-267. [CrossRef] [PubMed]

36. Regalado, N.G.; Martin, G.; Antony, S.J. Acinetobacter lwoffii: Bacteremia associated with acute gastroenteritis. Travel. Med. Infect. Dis. 2009, 7, 316-317. [CrossRef] [PubMed]

37. Senneby, E.; Göransson, L.; Weiber, S.; Rasmussen, M. A population-based study of aerococcal bacteraemia in the MALDI-TOF MS-era. Eur. J. Clin. Microbiol. Infect. Dis. 2016, 35, 755-762. [CrossRef]

38. Kaboré, W.A.D.; Konaté, A.; Dembélé, R.; Konaté, R.; Faye, B.; Ouédraogo, D.; Boisramé, S.; Traoré, A.S.; Barro, N.; Sangaré, L. Occurrence and Antibiotic Susceptibility of Aerococcus and Enterococcus Strains Isolated from Acute and Chronic Cellulites of Dental Origin in Ouagadougou, Burkina Faso. J. Dent. Oral Care Med. 2016, 2, 104.

39. Yadav, K.; Sharma, M.; Agarwal, S.; Bhatia, N.; Yadav, N. Aortic pseudoaneurysm \& endocarditis caused by Aerococcus viridans: A case report and literature review. Cardiovasc. Revasc. Med. 2018, 19, 201-203. [PubMed]

40. Abboud, A.A.; Ahmad, S.O.; Habli, M.M.; Bechara, C. Aerococcus Viridians: Under-Recognized Cause of Pyomyositis. Clin. Microbiol. 2016, 5, 2.

41. Mohan, B.; Zaman, K.; Anand, N.; Taneja, N. Aerococcus viridans: A rare pathogen causing urinary tract infection. J. Clin. Diagn. Res. 2017, 11, DR01-DR03. [CrossRef]

42. Janda, J.M.; Abbott, S.L. The genus Aeromonas: Taxonomy, pathogenicity, and infection. Clin. Microbiol. Rev. 2010, 23, 35-73. [CrossRef]

43. Vila, J.; Ruiz, J.; Gallardo, F.; Vargas, M.; Soler, L.; Figueras, M.J.; Gascon, J. Aeromonas spp. and traveler's diarrhea: Clinical features and antimicrobial resistance. Emerg. Infect. Dis. 2003, 9, 552-555. [CrossRef] [PubMed]

44. Grass, G.; Bierbaum, G.; Molitor, E.; Götte, N.; Antwerpen, M. Genome Sequence of Bacillus pumilus Strain Bonn, Isolated from an Anthrax-Like Necrotic Skin Infection Site of a Child. Genome Announc. 2016, 4, e01741-15. [CrossRef] [PubMed]

45. Tena, D.; Martínez-Torres, J.Á.; Pérez-Pomata, M.T.; Sáez-Nieto, J.A.; Rubio, V.; Bisquert, J. Cutaneous infection due to Bacillus pumilus: Report of 3 cases. Clin. Infect. Dis. 2007, 44, e40-e42. [CrossRef]

46. Kimouli, M.; Vrioni, G.; Papadopoulou, M.; Koumaki, V.; Petropoulou, D.; Gounaris, A.; Friedrich, A.W.; Tsakris, A. Two cases of severe sepsis caused by Bacillus pumilus in neonatal infants. J. Med. Microbiol. 2012, 61, 596-599. [CrossRef] [PubMed]

47. Shivamurthy, V.M.; Gantt, S.; Reilly, C.; Tilley, P.; Guzman, J.; Tucker, L. Bacillus pumilus septic arthritis in a healthy child. Can. J. Infect. Dis. Med. Microbiol. 2016, 2016, 3265037. [CrossRef]

48. Mishra, R.; Kelly, P.; Toolsie, O.; Ayyadurai, P.; Adrish, M. Uncommon cause of fungemia in a patient with renal cell cancer: A case report of Candida lusitaniae Fungemia. Medicine 2017, 96, e8510. [CrossRef] [PubMed]

49. Bini Viotti, J.; Corzo-Pedroza, M.; Gonzales Zamora, J.A. Prosthetic joint infection caused by Candida lusitaniae: Report of a unique case. Acta Clin. Belg. 2018, 74, 286-291. [CrossRef]

50. Basra, P.; Koziol, A.; Wong, A.; Carrillo, C.D. Complete genome sequences of Citrobacter braakii strains GTA-CB01 and GTA-CB04, isolated from ground beef. Genome Announc. 2015, 3, e01307-e01314. [CrossRef] [PubMed]

51. Hirai, J.; Uechi, K.; Hagihara, M.; Sakanashi, D.; Kinjo, T.; Haranaga, S.; Fujita, J. Bacteremia due to Citrobacter braakii: A case report and literature review. J. Infect. Chemother. 2016, 22, 819-821. [CrossRef] 
52. Liu, L.-H.; Wang, N.-Y.; Wu, A.Y.-J.; Lin, C.-C.; Lee, C.-M.; Liu, C.-P. Citrobacter freundii bacteremia: Risk factors of mortality and prevalence of resistance genes. J. Microbiol. Immunol. Infect. 2018, 51, 565-572. [CrossRef]

53. Guermazi-Toumi, S.; Boujlel, S.; Assoudi, M.; Issaoui, R.; Tlili, S.; Hlaiem, M.E. Susceptibility profiles of bacteria causing urinary tract infections in Southern Tunisia. J. Glob. Antimicrob. Resist. 2018, 12, 48-52. [CrossRef]

54. Salih, M.K.; Alrabadi, N.I.; Thalij, K.M.; Hussien, A.S. Isolation of pathogenic gram-negative bacteria from urinary tract infected patients. Open J. Med. Microbiol. 2016, 6, 59-65. [CrossRef]

55. Duran, A.; Abacilar, A.F.; Uyar, I.S.; Akpinar, M.B.; Sahin, V.; Okur, F.F.; Ates, M.; Alayunt, E.A. Comamonas testosteroni endocarditis in Turkey: A case report and review of the literature. Sifa. Med. J. 2015, 2, 44-47. [CrossRef]

56. Farshad, S.; Norouzi, F.; Aminshahidi, M.; Heidari, B.; Alborzi, A. Two cases of bacteremia due to an unusual pathogen, Comamonas testosteroni in Iran and a review literature. J. Infect. Dev. Ctries. 2012, 6, 521-525. [CrossRef] [PubMed]

57. Orsini, J.; Tam, E.; Hauser, M.; Rajayer, S. Polymicrobial Bacteremia Involving Comamonas testosteroni. Case Rep. Med. 2014, 2014, 578127. [CrossRef] [PubMed]

58. Farooq, S.; Farooq, R.; Nahvi, N. Comamonas testosteroni: Is It Still a Rare Human Pathogen? Case Rep. Gastroenterol. 2017, 11, 42-47. [CrossRef] [PubMed]

59. Raphael, R.; Riley, L.W. Infections Caused by Antimicrobial Drug-Resistant Saprophytic Gram-Negative Bacteria in the Environment. Front. Med. 2017, 4, 1-17. [CrossRef]

60. Tymensen, L.; Booker, C.W.; Hannon, S.J.; Cook, S.R.; Zaheer, R.; Read, R.; McAllister, T.A. Environmental growth of enterococci and Escherichia coli in feedlot catch basins and a constructed wetland in the absence of fecal input. Environ. Sci. Technol. 2017, 51, 5386-5395. [CrossRef]

61. Dicpinigaitis, P.V.; De Aguirre, M.; Divito, J. Enterococcus hirae bacteremia associated with acute pancreatitis and septic shock. Case Rep. Infect. Dis. 2015, 2015, 123852.

62. Lee, G.H.; Lee, H.W.; Lee, Y.J.; Park, B.S.; Kim, Y.W.; Park, S. Acute Pyelonephritis with Enterococcus hirae and Literature Review. Urogenit. Tract. Infect. 2017, 12, 49-53. [CrossRef]

63. Pãosinho, A.; Azevedo, T.; Alves, J.V.; Costa, I.A.; Carvalho, G.; Peres, S.R.; Baptista, T.; Borges, F.; Mansinho, K. Acute pyelonephritis with bacteremia caused by Enterococcus hirae: A rare infection in humans. Case Rep. Infect. Dis. 2016, $2016,4698462$.

64. Bourafa, N.; Loucif, L.; Boutefnouchet, N.; Rolain, J.M. Enterococcus hirae, an unusual pathogen in humans causing urinary tract infection in a patient with benign prostatic hyperplasia: First case report in Algeria. New Microbes New Infect. 2015, 8 , 7-9. [CrossRef]

65. Edgeworth, J.D. Bacterial gastroenteritis. Medicine 2005, 33, 73-77. [CrossRef]

66. Dib, R.W.; Matar, M.; Hallak, R.; Farra, A.; Mokhbat, J. Gemella hepatic abscesses: A case report and review of the literature. J. Infect. Dev. Ctries. 2018, 12, 146-149.

67. Mneimneh, S.; Awada, H.; Shatila, A. A Child with Brain Abscess Due to Gemella haemolysans. ECPE 2016, 2, 139-142.

68. Ando, A.; Kagihara, J.; Chung, H.; Bolger, D.T., Jr. Case Report: Native bivalvular endocarditis by Gemella haemolysans requiring venovenous extracorporeal membrane oxygenation. BMJ Case Rep. 2016, bcr2016216029. [CrossRef]

69. Abu-Heija, A.A.; Ajam, M.; Veltman, J. Gemella morbillorum Cryptogenic Brain Abscess: A Case Report and Literature. Cureus 2018, 10, e3612. [CrossRef]

70. Li, D.; Zhu, Z.; Zheng, X.; Wang, W.; Xu, R.; Liu, K. Gemella morbillorum endocarditis of pulmonary valve: A case report. J. Cardiothorac. Surg. 2017, 12, 16. [CrossRef] [PubMed]

71. Rial, L.; Schargel, K.; Rial, A.; Ortega, L.; Belda, J.I. Late-Onset Gemella morbillorum Flap-Margin-Related Keratitis After Laser In Situ Keratomileusis. J. Clin. Case Rep. 2016, 6, 885. [CrossRef]

72. Paczosa, M.K.; Mecsas, J. Klebsiella pneumoniae: Going on the offense with a strong defense. Microbiol. Mol. Biol. Rev. 2016, 80, 629-661. [CrossRef] [PubMed]

73. Davis, G.S.; Price, L.B. Recent research examining links among Klebsiella pneumoniae from food, food animals, and human extraintestinal infections. Curr. Environ. Health Rep. 2016, 3, 128-135. [CrossRef]

74. Holt, K.E.; Wertheim, H.; Zadoks, R.N.; Baker, S.; Whitehouse, C.A.; Dance, D.; Jenney, A.; Connor, T.R.; Hsu, L.Y.; Severin, J.; et al. Genomic analysis of diversity, population structure, virulence, and antimicrobial resistance in Klebsiella pneumoniae, an urgent threat to public health. Proc. Natl. Acad. Sci. USA 2015, 112, E3574-E3581. [CrossRef] [PubMed]

75. Kwon, T.; Jung, Y.H.; Lee, S.; Yun, M.R.; Kim, W.; Kim, D.W. Comparative genomic analysis of Klebsiella pneumoniae subsp. pneumoniae KP617 and PittNDM01, NUHL24835, and ATCC BAA-2146 reveals unique evolutionary history of this strain. Gut Pathog. 2016, 8, 34. [PubMed]

76. Sarria, J.C.; Vidal, A.M.; Kimbrough, R.C. Infections Caused by Kluyvera Species in Humans. Clin. Infect. Dis. 2001, 33, e69-e74. [CrossRef]

77. Alfreijat, M. A Case of Urinary Tract Infection and Severe Sepsis Caused by Kluyvera ascorbata in a 73-Year-Old Female with a Brief Literature Review. Case Rep. Infect. Dis. 2017, 2017, 3848963.

78. Yoshino, Y.; Nakazawa, S.; Otani, S.; Sekizuka, E.; Ota, Y. Nosocomial bacteremia due to Kluyvera cryocrescens: Case report and literature review. IDCases 2016, 4, 24-26. [CrossRef]

79. Erbasan, F. Brain abscess caused by Micrococcus luteus in a patient with systemic lupus erythematosus: Case-based review. Rheumatol. Int. 2018, 38, 2323-2328. [CrossRef] 
80. Yan, S.F.; Liu, X.Y.; Cheng, Y.F.; Li, Z.Y.; Ou, J.; Wang, W.; Li, F.Q. Relationship between intrauterine bacterial infection and early embryonic developmental arrest. Chin. Med. J. 2016, 129, 1455-1458. [CrossRef]

81. Baumbach, S.F.; Prall, W.C.; Scharpf, A.M.; Hererich, V.; Schmidt, M.; Suedkamp, N.P.; Stoehr, A.; Mayr, H.O. Significant increase of pathogen detection rate by dry arthroscopic biopsies at suspected low-grade infection following total knee arthroplasty: A prospective observational study. Arch. Orthop. Trauma. Surg. 2018, 138, 1583-1590. [CrossRef]

82. Shima, A.; Hinenoya, A.; Samosornsuk, W.; Samosornsuk, S.; Mungkornkaew, N.; Yamasaki, S. Prevalence of Providencia strains among patients with diarrhea and in retail meats in Thailand. Jpn. J. Infect. Dis. 2016, 69, 323-325. [CrossRef] [PubMed]

83. Yoh, M.; Matsuyama, J.; Ohnishi, M.; Takagi, K.; Miyagi, H.; Mori, K.; Park, K.S.; Ono, T.; Honda, T. Importance of Providencia species as a major cause of travellers' diarrhoea. J. Med. Microbiol. 2005, 54, 1077-1082. [CrossRef] [PubMed]

84. Shah, M.M.; Odoyo, E.; Larson, P.S.; Apondi, E.; Kathiiko, C.; Miringu, G.; Nakashima, M.; Ichinose, Y. First report of a foodborne Providencia alcalifaciens outbreak in Kenya. Am. J. Trop. Med. Hyg. 2015, 93, 497-500. [CrossRef] [PubMed]

85. Choi, W.; Ji, Y.S.; Yoon, K.C. A case of bilateral keratitis caused by Providencia alcalifaciens: A rarely encountered ocular pathogen. Int. Ophthalmol. 2018, 38, 1325-1328. [CrossRef]

86. Luczkiewicz, A.; Kotlarska, E.; Artichowicz, W.; Tarasewicz, K.; Fudala-Ksiazek, S. Antimicrobial resistance of Pseudomonas spp. isolated from wastewater and wastewater-impacted marine coastal zone. Environ. Sci. Pollut. Res. 2015, 22, 19823-19834. [CrossRef] [PubMed]

87. Gershman, M.D.; Kennedy, D.J.; Noble-Wang, J.; Kim, C.; Gullion, J.; Kacica, M.; Jensen, B.; Pascoe, N.; Saiman, L.; McHale, J.; et al. Multistate outbreak of Pseudomonas fluorescens bloodstream infection after exposure to contaminated heparinized saline flush prepared by a compounding pharmacy. Clin. Infect. Dis. 2008, 47, 1372-1379. [CrossRef]

88. Nishimura, T.; Hattori, K.; Inoue, A.; Ishii, T.; Yumoto, T.; Tsukahara, K.; Nakao, A.; Ishihara, S.; Nakayama, S. Bacteremia or pseudobacteremia? Review of Pseudomonas fluorescens infections. World J. Emerg. Med. 2017, 8, 151-154. [CrossRef] [PubMed]

89. Huang, C.R.; Lien, C.Y.; Tsai, W.C.; Lai, W.A.; Hsu, C.W.; Tsai, N.W.; Chang, C.C.; Lu, C.H.; Chien, C.C.; Chang, W.N. The clinical characteristics of adult bacterial meningitis caused by non-Pseudomonas (Ps.) aeruginosa Pseudomonas species: A clinical comparison with Ps. aeruginosa meningitis. Kaohsiung. J. Med. Sci. 2018, 34, 49-55. [CrossRef]

90. Kalra, D.; Sati, A.; Shankar, S.; Jha, A. Corneal infection by Pseudomonas stutzeri following excision of trigeminal nerve schwannoma. BMJ Case Rep. 2015, 2015, bcr2014207496. [CrossRef]

91. Halabi, Z.; Mocadie, M.; El Zein, S.; Kanj, S.S. Pseudomonas stutzeri prosthetic valve endocarditis: A case report and review of the literature. J. Infect. Public Health 2019, 12, 434-437. [CrossRef]

92. Shalabi, A.; Ehrlich, T.; Schäfers, H.J.; Becker, S.L. Infective endocarditis caused by Pseudomonas stutzeri in a patient with Marfan syndrome: Case report and brief literature review. IDCases 2017, 10, 22-25. [CrossRef]

93. Bonares, M.J.; Vaisman, A.; Sharkawy, A. Prosthetic vascular graft infection and prosthetic joint infection caused by Pseudomonas stutzeri. IDCases 2016, 6, 106-108. [CrossRef]

94. Kumar, M.S.; Das, A.P. Molecular identification of multi drug resistant bacteria from urinary tract infected urine samples. Microb. Pathog. 2016, 98, 37-44. [CrossRef] [PubMed]

95. Boattini, M.; Almeida, A.; Cardoso, C.; Cruz, C.S.; Machado, C.; Vesza, Z.; Tosatto, V.; Maia, D.; Cardoso, S.; Pinto, M.; et al. Infections on the rise: Raoultella spp., clinical and microbiological findings from a retrospective study, 2010-2014. Infect. Dis. 2016, 48, 87-91. [CrossRef] [PubMed]

96. Yumoto, T.; Naito, H.; Ihoriya, H.; Tsukahara, K.; Ota, T.; Watanabe, T.; Nakao, A. Raoultella planticola bacteremia-induced fatal septic shock following burn injury. Ann. Clin. Microbiol. Antimicrob. 2018, 17, 19. [CrossRef] [PubMed]

97. Demiray, T.; Koroglu, M.; Ozbek, A.; Altindis, M. A rare cause of infection, Raoultella planticola: Emerging threat and new reservoir for carbapenem resistance. Infection 2016, 44, 713-717. [CrossRef] [PubMed]

98. Cho, Y.J.; Jung, E.J.; Seong, J.S.; Woo, Y.M.; Jeong, B.J.; Kang, Y.M.; Lee, E. A case of pneumonia caused by Raoultella planticola. Tuberc. Respir. Dis. 2016, 79, 42-45. [CrossRef]

99. Skelton, W.P., IV; Taylor, Z.; Hsu, J. A rare case of Raoultella planticola urinary tract infection in an immunocompromised patient with multiple myeloma. IDCases 2017, 8, 9-11. [CrossRef]

100. Carrero, P.; Garrote, J.A.; Pacheco, S.; García, A.I.; Gil, R.; Carbajosa, S.G. Report of six cases of human infection by Serratia plymuthica. J. Clin. Microbiol. 1995, 33, 275-276. [CrossRef]

101. Jain, S.; Jain, S.; Jain, R.; Kaur, I.R. Serratia plymuthica: A community-acquired uropathogen. Indian J. Med. Sci. 2017, 69, 31-32. [CrossRef]

102. Vignier, N.; Barreau, M.; Olive, C.; Baubion, E.; Théodose, R.; Hochedez, P.; Cabié, A. Human infection with Shewanella putrefaciens and S. algae: Report of 16 cases in Martinique and review of the literature. Am. J. Trop. Med. Hyg. 2013, 89, 151-156. [CrossRef] [PubMed]

103. Becker, K.; Heilmann, C.; Peters, G. Coagulase-negative staphylococci. Clin. Microbiol. Rev. 2014, 27, 870-926. [CrossRef] [PubMed]

104. Tong, S.Y.; Davis, J.S.; Eichenberger, E.; Holland, T.L.; Fowler, V.G. Staphylococcus aureus infections: Epidemiology, pathophysiology, clinical manifestations, and management. Clin. Microbiol. Rev. 2015, 28, 603-661. [CrossRef] [PubMed]

105. Elbashir, S.; Parveen, S.; Schwarz, J.; Rippen, T.; Jahncke, M.; DePaola, A. Seafood pathogens and information on antimicrobial resistance: A review. Food Microbiol. 2018, 70, 85-93. [CrossRef] 
106. De Vecchi, E.; George, D.A.; Romanò, C.L.; Pregliasco, F.E.; Mattina, R.; Drago, L. Antibiotic sensitivities of coagulase-negative staphylococci and Staphylococcus aureus in hip and knee periprosthetic joint infections: Does this differ if patients meet the International Consensus Meeting Criteria? Infect. Drug. Resist. 2018, 11, 539-546. [CrossRef]

107. Czekaj, T.; Ciszewski, M.; Szewczyk, E.M. Staphylococcus haemolyticus-An emerging threat in the twilight of the antibiotics age. Microbiology 2015, 161, 2061-2068. [CrossRef] [PubMed]

108. Williford, S.; Heavner, M.; Lambing, T.; Wian, B.; Ma, S.; Gonzales, J. 704: When "contaminants" become pathogens Staphylococcus auricularis bacteremia in the critically ill. Crit. Care Med. 2018, 46, 338. [CrossRef]

109. Geller, J.A.; MacCallum, K.P.; Murtaugh, T.S.; Patrick, D.A., Jr.; Liabaud, B.; Jonna, V.K. Prospective comparison of blood culture bottles and conventional swabs for microbial identification of suspected periprosthetic joint infection. J. Arthroplast. 2016, 31, 1779-1783. [CrossRef]

110. Ahmad, S.S.; Ali, F.A. Microbiological Study of Pathogens Isolated From Women with Genital Tract Infection. Int. J. Med. Res. 2015, 1, 95-105.

111. Bhattacharya, G.; Dey, D.; Bhattacharya, A.; Das, S.; Banerjee, A. Bacteraemia by Staphylococcus cohnii subsp. urealyticus in a diabetic patient: A case report. World J. Pharm. Pharm. Sci. 2016, 5, 1864-1869.

112. Garg, S. Staphylococcus cohnii: Not so innocuous. J. Acute Dis. 2017, 6, 239-240. [CrossRef]

113. Shahandeh, Z.; Shafi, H.; Sadighian, F. Association of staphylococcus cohnii subspecies urealyticum infection with recurrence of renal staghorn stone. Caspian J. Intern. Med. 2015, 6, 40-42.

114. Hetsa, B.A.; Kumar, A.; Ateba, C.N. Characterization of multiple antibiotic resistant clinical strains of Staphylococcus isolated from pregnant women vagina. Folia Microbiol. 2018, 63, 607-617. [CrossRef] [PubMed]

115. Campoccia, D.; Montanaro, L.; Visai, L.; Corazzari, T.; Poggio, C.; Pegreffi, F.; Maso, A.; Pirini, V.; Ravaioli, S.; Cangini, I.; et al. Characterization of 26 Staphylococcus warneri isolates from orthopedic infections. Int. J. Artif. Organs 2010, 33, 575-581. [CrossRef] [PubMed]

116. Stepanović, S.; Dakić, I.; Martel, A.; Vaneechoutte, M.; Morrison, D.; Shittu, A.; Ježek, P.; Decostere, A.; Devriese, L.A.; Haesebrouck, F. A comparative evaluation of phenotypic and molecular methods in the identification of members of the Staphylococcus sciuri group. Syst. Appl. Microbiol. 2005, 28, 353-357. [CrossRef] [PubMed]

117. Szczuka, E.; Krzymińska, S.; Kaznowski, A. Clonality, virulence and the occurrence of genes encoding antibiotic resistance among Staphylococcus warneri isolates from bloodstream infections. J. Med. Microbiol. 2016, 65, 828-836. [CrossRef]

118. Bhardwaj, B.; Bhatnagar, U.B.; Conaway, D.G. An Unusual Presentation of Native Valve Endocarditis caused by Staphylococcus warneri. Rev. Cardiovasc. Med. 2016, 17, 140-143.

119. Kuvhenguhwa, M.S.; Belgrave, K.O.; Shah, S.U.; Bayer, A.S.; Miller, L.G. A Case of Early Prosthetic Valve Endocarditis Caused by Staphylococcus warneri in a Patient Presenting with Congestive Heart Failure. Cardiol. Res. 2017, 8, 236-240. [CrossRef]

120. Ivić, I.; Karanović, J.; Pavičić-Ivelja, M. Sepsis with multiple abscesses caused by staphylococcus warneri: A case report. Cent. Eur. J. Med. 2013, 8, 45-47. [CrossRef]

121. Dimitriadi, D.; Charitidou, C.; Charvalos, E. Urinary tract infection due to beta-lactams-resistant Staphylococcus warneri: A case report. Int. J. Antimicrob. Agents 2015, 4, 3. [CrossRef]

122. Zhi, A.; Ma, B.; Wu, Y.; Fang, J.; Yu, X.; Zhang, M. Detection of Viable Vibrio cholerae Cells in Seafood Using a Real-Time Visual Loop-Mediated Isothermal Amplification Combined with Propidium Monoazide. Food Anal. Methods 2018, 11, 99-110. [CrossRef]

123. Karaiskos, I.; Giamarellou, H. Multidrug-Resistant and Extensively Drug-Resistant Gram-Negative Pathogens: Current and Emerging Therapeutic Approaches. Exp. Opin. Pharmacother. 2014, 15, 1351-1370. [CrossRef] [PubMed]

124. Shaikh, S.; Pandya, H. Comparison of Colistin Susceptibility Testing by VITEK 2 Compact and Broth Microdilution Method for Carbapenem Resistant Isolates in a Tertiary Diagnostic Centre. J. Clin. Nephrol. Kidney Dis. 2019, 4, 1024.

125. Müller, H.; Sib, E.; Gajdiss, M.; Klanke, U.; Lenz-Plet, F.; Barabasch, V.; Albert, C.; Schallenberg, A.; Timm, C.; Zacharias, N.; et al. Dissemination of multi-resistant gram-negative bacteria into Germanwastewater and surfacewaters. FEMS Microbiol. Ecol. 2018, 94, fiy057. [CrossRef]

126. Roberts, R.R.; Hota, B.; Ahmad, I.; Scott, R.D.; Foster, S.D.; Abbasi, F.; Schabowski, S.; Kampe, L.M.; Ciavarella, G.G.; Supino, M.; et al. Hospital and Societal Costs of Antimicrobial-Resistant Infections in a Chicago Teaching Hospital: Implications for Antibiotic Stewardship. Clin. Infect. Dis. 2009, 49, 1175-1184. [CrossRef]

127. Schreiber, C.; Zacharias, N.; Essert, S.M.; Wasser, F.; Müller, H.; Siba, E.; Precht, T.; Parcina, M.; Bierbaumb, G.; Schmithausen, R.M.; et al. Clinically relevant antibiotic-resistant bacteria in aquatic environments-An optimized culture-based approach. Sci. Total Environ. 2021, 750, 142265. [CrossRef] [PubMed]

128. Zhen, X.; Lundborg, C.S.; Sun, X.; Hu, X.; Dong, H. Economic burden of antibiotic resistance in ESKAPE organisms: A systematic review. Antimicrob. Resist. Infect. Control 2019, 8, 137. [CrossRef]

129. Jafari, A.; Aslani, M.M.; Bouzari, S. Escherichia coli: A brief review of diarrhoeagenic patho-types and their role in diarrheal diseases in Iran. Iran. J. Microbiol. 2012, 4, 102-117.

130. Gomi, R.; Matsuda, T.; Fujimori, Y.; Harada, H.; Matsui, Y.; Yoneda, M. Characterization of pathogenic Escherichia coli in river water by simultaneous detection and sequencing of 14 virulence genes. Environ. Sci. Technol. 2015, 49, 6800-6807.

131. Morabito, S. Pathogenic Escherichia coli, Molecular and Cellular Microbiology; Caister Academic Press: Norfolk, UK, $2014 ;$ pp. 1-273.

132. Fratamico, P.M.; Liu, Y.; Sommers, H. Pathogenic Escherichia coli, Evolution omics, Detection and Control; Caister Academic Press: Norfolk, UK, 2018; pp. 1-249. 
133. Kaper, J.B.; Nataro, J.P.; Mobley, H.L.T. Pathogenic Escherichia coli. Nat. Rev. Microbiol. 2004, 2, 123-140. [CrossRef]

134. Croxen, M.A.; Law, R.J.; Scholz, R.; Keeney, K.M.; Wlodarska, M.; Finlay, B.B. Recent Advances in Understanding Enteric Pathogenic Escherichia coli. Clin. Microbiol. Rev. 2013, 26, 822-880. [CrossRef] [PubMed]

135. Marie, V.; Lin, J. Microbial Indicators and Environmental Relationships in the Umhlangane River, Durban, South Africa; De Gruyter: Berlin, Germany, 2018. Available online: https:/ /doi.org/10.1515/biol-2018-0047 (accessed on 28 May 2021).

136. World Health Organization (WHO). Guidelines for Drinking Water Quality, 3rd ed.; World Health Organization: Geneva, Switzerland, 2011.

137. Manaka, T.; Araoka, D.; Yoshimura, T.; Hossain, H.M.Z.; Nishio, Y.; Suzuki, A.; Kawahata, H. Downstream and seasonal changes of lithium isotope ratios in the Ganges-Brahmaputra river system. Adv. Earth Space Sci. 2017, 18, 3003-3015. [CrossRef]

138. Engwa, G.A.; Ferdinand, P.U.; Nwalo, F.N.; Unachukwu, M.N. Mechanism and Effects of Heavy Metal Toxicity in Humans, Poisoning in the Modern World—New Tricks for an Old Dog? Karcioglu, O., Arslan, B., Eds.; IntechOpen: London, UK, 2018. Available online: https:/ / doi.org/10.5772/intechopen82511 (accessed on 5 June 2021). [CrossRef]

139. Campbell, L.A. The Waste Assimilation Capacity of a Reach of a Jukskei River Just Downstream of Alexandra Township Johannesburg: Research Group; University of the Witwatersrand: Johannesburg, South Africa, 1996.

140. Herbig, F.J.W. Talking dirty-effluent and sewage irreverence in South Africa: A conservation crime perspective. Cogent Soc. Sci. 2019, 5, 1701359. [CrossRef] 